\title{
FAKE NEWS AND THE RITUALISATION OF THE SELF
}

\author{
ELENI KARAS ${ }^{1}$ \\ ${ }^{1}$ University of Ioannina, Department of Primary Education, Mpizani 455 00, Ioannina, Greece. ORCID: \\ 0000-0003-0840-9161,Email: helenkapa@gmail.com
}

ABSTRACT: Two hundred years have passed since the question of subjectivity (re-interpreted through Kierkegaard's existentialism) became central in modern philosophy. Over these two centuries, multiple theories addressed and questioned the borders between authentic subjectivity and an internalized panopticon of the hegemonic views that dominate the subject. Nevertheless, they still have to be definitively defined. As we may try to point Fake News (FN) is an opponent to subjectivity, and yet it comes from the subject. FN is the intentional spreading through new technologies of false information on a global level by subjects that use social media, a process influencing not only the sense of socio-political reality but also the concept of identity. Identities (personal or collective) are in general the combination of the socially determined understanding of 'who I am' and the socially and psychologically influenced 'mental model' of 'what the world - and the self within it - should be', all expressed and produced under the fundamental influence of our idiosyncratic characteristics.

One of the fields that all these factors meet and interact is the new mediated environment where almost everyone can participate and contribute. According to the Sociology of Communication as founded by Giddens, Habermas and Luckmann (Leydesdorff 2000) this makes the public part of our identity the dominant one, creating a ritual in which our narcissistic elements dominate our private ones. The Self, addressing itself into the public like an echo and back to the Self, becomes ritualized. In our paper, we explore the interrelation of this phenomenon with the creation and distribution of Fake News, from the vantage point of Kierkegaard's existential philosophy. KEYWORDS: personal identity, socio-political identity, mediated identity, folklore, rituals, situated knowledge, discourse, narrative, existentialism, Kierkegaard 


\section{INTRODUCTION}

We live in an era of blistering changes that transform our perceptions of the world and its fundamental institutions profoundly. Moreover, they also change our concept of the Self and its fundamental functions. Identities, being in constant interaction with the sense of socio-political reality and influencing the directions that both the self and the world might take, become mediated, or else formed (to a certain extent) by the symbolic use of data that happens massively in the media. Nevertheless, to quote Fornas and Xynaris (2013: 11): 'a discussion of how identity formation issues links to the concept of new media literacies, forms a transition to three sections that in turn analyse the social trends, the policy trends and the scientific trends that may be discerned in this area'. In other words, the common question set here is: What is the exact relationship - and its dynamics - between our distant selves and a reality that becomes less and less concrete?

In that sense, a symposium about Fake News in accordance to Kierkegaard's philosophy, a philosophy that dared to set the comparison between concrete human reality and 'distant' abstract thinking based on individual, subjective choices, is of considerable significance and relevance with today's social needs and scientific trends. Communication, after all, was never perceived as wholly separated from philosophy. On the contrary, it was seen primarily as a social, psychological, possibly also a philosophical, term (Silverstone 2005). As it happens, in this new context, communication becomes a 'communicative event' in which the broader ideas, views, taken for granted assumptions, meanings, and most of all 'ideal selves' are part of a mediated identity and in particular contexts of use.

\section{RESEARCH METHODOLOGY}

This paper combines content analysis (i.e., studying documents) and triangulation (i.e., navigating texts and ideas) in order to explore the interrelations between this Ritualized Self and the Need for Fake News to be created and spread. It examines the concepts and propositions of Kierkegaard's texts, and specifically Concluding Unscientific Postscript, because Climacus, i.e., Kierkegaard's alter ego, explores and focuses on the notion of 'truth' in relation to 'reality' and 'subjectivity'. Assuming that Fake News as a phenomenon stands at the threshold of these notions, the analysis proceeds to break down some of Climacus thoughts into their constituent parts and partly comparing them with the constituent parts of the Fake News analysis. Kierkegaard's philosophical ideas are then utilised to gain knowledge about the subjective understanding of reality, the manipulation that may occur because of it, and the need to invent or reinvent it according to the neotribe we want to belong. Both may shed creative light into the philosophical issues in which the concept of Fake News is involved (Beaney 2003). 


\section{RESEARCH RESULTS}

The analysis leads to the conclusion that 'while in the traditional societies the social cohesion was constructed using the Unheimlich as an enemy, which led to the Ideal National (aka Collective) Self, in neoliberal societies of post-modernity the new Unheimlich is critical thinking and alas reality itself. The bitter irony, so close to Kierkegaard's critique to the press of his era, is that critical thinking led to a notion of pedagogy which identified the educational praxis with the creation not of a full mind (meaning full of information) but of an open mind, meaning able to absorb news ideas and emotions. Nevertheless, the open social space of contemporarily, linked with the sociological imagination, might lead to an ambiguous future of information, where our more personal space might be manipulative and under manipulation. Manipulated first by ourselves and then by the convincing others'.

\section{DISCUSSION}

As mentioned before, we live in an era where rapid changes impact society, economy and communication, challenging not only the ways we used to define our personal and collective 'Self' and the 'Other' but also their public manifestations. Interacting with our subculture and idiosyncrasy, the traditional groups or formations that used to firmly mould our worldview and identity, such as the Nation-State and the Church, or class and gender, seem to withdraw and new formations, like social media and their new tribes, to evolve, challenging our notion of locality and identity.

'Far from identity disappearing in contemporary society, it is rather reconstructed and redefined' wrote Douglas Kellner (Bauman 1992: 18), pointing out that 'identity today becomes a freely chosen game, a theatrical presentation of the self' and that 'when one radically shifts identity at will, one might lose control'. It seems a hegemonic shift to evolve, from the stable, dominant forms that the 'great narratives' (Lyotard 1984) used in order to establish the power relations, to a complex network of cultural micro powers that our narratives use in order to recreate a sense of 'a self' or a 'reality', in a multi-segmented world that everything might be assimilations. Including news and 'truths'. 'Fake News' and 'fake truths' created by any 'anon' in Facebook or any institution or political force in this vast network of micro powers. A vast, global network spread among us like the 'bugs' of the Empire of the Self of the abandoned, isolated and yet having the false believe of being in the centre of it all individual, to quote Cristopher Star (2012) and his question of how political reality affects the concepts of body, soul, and self.

\section{A PIONEER OF THE MEDIATED IDENTITY OR A REBEL OF AN EVOLVING IN- NER INDEPENDENCE?}

Kierkegaard dared to ask how the interrelation between reality and the self, objectivity and subjectivity, between the choice of faith or the lack of it, affects the concepts of body, soul, and self. In an era where religion was the ultimate source of any legitimate worldview's construction, Kierkegaard is well known for claiming that in 
religious matters 'truth is subjectivity'. 'Objectively there is no truth' claims Johannes Climacus, (Kierkegaard 1992: 224) his alter ego, in Concluding Unscientific Postscript. By claiming that 'an objective knowledge about the truth does not exist' Climacus challenged any 'ultimate source' from which the one and only truth derives, and he brought in the mainstream the social subject as the only real responsible for seeking his or her truth.

Kierkegaard expelled the social subject into a chaotic environment of no solid worldview, of no solid identity, of not a unique logical 'reality'. This environment seems so similar to the chaotic mediated world of the modern social subject where there are no stable ideas, 'truths', or solid groups to construct our identity. In other words, in chaos were 'you', as a person, from the complicated 'ocean' of controversial information, should decide what to believe or not.

Nevertheless, does this mean that Kierkegaard was an ancestor of the Fake News mentality? Was he a pioneer of the multiple forms of 'reality' and the excuses we make for it, where 'Truth', (named as God or Paradise or Social Justice or actual Personal happiness or Professional success under the influence of various narratives that mark humanity since Moses and Odysseus), the monomyth that humanity never seize to search in order to complete itself, stops to exist and no one cares to proceed into a quest for it?

Climacus says: 'The way the objective truth goes away from the subject, and while the subject and subjectivity become indifferent, the truth becomes indifferent, and that is precisely its objective validity, because the interest, just like the decision is subjectivity' (Kierkegaard 1992: 193). Moreover, with this simple line Kierkegaard separates philosophy or even faith, from one-dimensional perspectives of absolute truth and the monocultural totalitarian beliefs or 'goals' (never completely innocent) that go along with them and he - along with other great minds - constructs the foundation stone of the modern, contradictions and evolving in his/her identity, social subject.

Let us consider, having as a given the various differentiation from one era to the other if these characteristics describe the general context of modern mediated environments in their most reliable form. In other words, if Climacus seems to introduce the subject, from a keyhole, to the historical future, or in fact to the reasons why persons and societies need to crate and use Fake News.

\section{IS FAKE NEWS BASED ON SUBJECTIVITY OR THE LACK OF IT?}

For Climacus, the very notion of faith would make no sense if based on proof. As Kierkegaard wrote: 'Without risk, there is no faith. Faith is the contradiction between the infinite passion of inwardness and objective uncertainty. If I am able to apprehend God objectively, I do not have faith; but because I cannot do this, I must have faith' (Kierkegaard 1992: 204). In other words, God is interested in many things but one. To 'empirically manifest' Itself. Furthermore, Man, according to Climacus, is able for many things, too. Nevertheless, one of the things he or she cannot do is to realise God empirically.

Of course, Kierkegaard, aka Climacus, addresses the concept of faith and implies 
that faith is not related to evidence or proof. There is no 'objective' faith (a daring thing to say even in his era), on the contrary faith is based on 'existential' needs, on personal interests, on an objective understanding of realities.

It is akin to claiming that the choices upon which the faith is based, or absence thereof, became a nickname for autobiographical narrations that challenge faith as a constructed worldview. It would then also turn into the significant mark of our personal rationality toward the Self and the World and its generalized irrationality.

In other words, its relativism has nothing to do with irrationality in the first place. Of course, seeking safety and comfort, we tend to excuse irrational attitudes related to our personal or collective self, choosing to be blind or arrogant with our actions and the motives beneath them. Nevertheless, there seems to be a very moral, or at least understandable, quest under the need or the choice of faith. The need to bring order into chaos, justice in the explanation of pain, cause in the eternal vanity. In other words, Truth. Faith, as a personal narrative, as an existential need, has a therapeutic ethos easing the given dystopias, not creating new ones in the name of actual profit.

Here lies a significant difference as well as an essential similarity with today's Fake News: both religious faith and Fake News, aka mediated faith, are based on an arbitrary decision that aims to ease the cognitive and sentimental conflict between the self and reality. From the ocean of information, one chooses to believe those who comfort them and reassures their worldview or ideology. Nevertheless, concerning faith, what Climacus means by objective uncertainty is not, empirical uncertainty, but rather the kind of uncertainty that accrues to making certain existential choices' (Schönbaumsfeld 2010: 133).

Kierkegaard separates faith from objectivity, not from Reality. He does not involve the latter; neither tries to manipulate it. He respectfully lets it be. This would be a crucial point if we wanted to realise the similarities and dissimilarities between Climacus subjectivity and Fake News.

Because the later abandon subjectivity and claim for themselves the objective truth at the expense of one's mind, regardless if they distort reality according to their new tribe's interests or sentimental investments. Were Climacus, aka Kierkegaard, expresses the need to construct a social subject able to choose to believe or not, Fake News aim to deconstruct any kind of a substantial social subject and replace it with a manipulated and yet manipulative member of a new tribalistic perception that, to a certain degree and in many cases, erase society and critical thinking imposing fakery as truth.

\section{FAKE NEWS, THE NOTION OF SUBJECTIVITY AND NEOTRIBALISM}

According to social psychology, any significant change in societal or psychological level that causes difficulties creates intense anxiety and the need to negotiate the 'old' and the 'new' in order to adjust in the new reality (Bauman 1992).

The power of fear and the need for happiness are equal (Adorno 2017:223) the inevitable contradictions of the human condition. Trauma reflects both, transforming each other in a constant dialogue, that mediates the various expressions of our sociopsychological transformations. 
The significant transitions that societies face globally carry a variety of changing functions in the societal financial and cultural field. Those functions, never wholly liberated from the hegemonic discourses, are at the same time associated with the acceptance or the disapproval of reality, the other and the self-inside its realm. Such acceptance or disapproval underlie the socio-psychological strategies groups create in order to adjust to an evolving world.

As it has already been pointed out, one of these strategies, aiming to eliminate the growing anxiety of our chaotic actual and virtual world, is people to seek safety and confirmation of their identity (this combination of self and world view) inside of neo tribes. In other words, in the effort to adjust our self in this new brave world ${ }^{1}$. The selection is performed among multiple pieces of information what creates less cognitive and emotional conflict, what challenges least likely the narcissistic perception of our self and our ideological ethical or practical choices. This selectivity, this subjectivity, is hidden under 'rational' or 'ethical' criteria that domesticate the mediated perceptions of the world. It is in a sense a transfer of the old Self and the convenient World we used to know, or we aimed to live into the multi-cultural field of the complicated socio-political realities, using selective criteria of a 'proper' reality.

\section{HOWEVER, IS THIS SUBJECTIVITY RELATED TO KIERKEGAARD'S SUBJECTIV- ITY?}

Sociologist Michel Maffesoli was perhaps the first to argue in a scholarly context that individuals have the growing urge to live in tribal communities, as opposed to mass society, and thus will naturally form social networks constituting new tribes. Although Maffesoli meant it as an evolution in the actual social field, new, constantly evolving technologies gave it a new dynamic and perspective. Ulrich Beck (1992) argued about how the technological risks function in the context of the so-called second modernity, in order to expose their implications in terms of new forms of reflexivity in complex societies and evolving selves.

A Self never wholly liberated from the 'naturalization processes' and the hegemonic forces, the gatekeepers of this new mediated world. Because no matter if the world seems multi fragmented in isolated selves, interacting with each other through their PCs, still 'identities in an era of postcolonialism, neoliberalism, and transnational media, promote the cultivation of a global proletariat in the context of the complex, vibrant, and hybridized cultures that crosscut the globe' (Durcham 2009: 27; McMillin 2009).

Nevertheless, since these beliefs frequently involve cases of false ideology and inner impositions of naturalised hegemonic views, this antithesis is a contradiction that makes people think for themselves something that might very well be (or is, in fact) an imposition of hegemonic forces. The manipulation they exercise upon our individual needs is proven faith's most significant, most controversial and most dominant characteristic.

\footnotetext{
${ }^{1}$ Shakespeare, W. 2013, The Tempest, Cambridge University Press. This quote is also used in Arthur Huxley's book challenging a dystopian future were mass media will be broadly used for manipulation.
} 
The involvement in treatises and the choice to believe into Fake News without second thoughts, without the responsibility to search and proceed critically, reveals a therapeutic function, that tries to solve in the field of representations what is unsolved, or not easily solved, in the field of reality - leading to the question whether there is any similarity to the criteria we use to believe God?

Climacus believes that it is impossible for any, existing being to apprehend truth from the point of eternity (sub specie aeterni) All paganism consists in this, that God is related directly to a human being, 'as the remarkably striking to the amazed' (Kierkegaard 1992: 245). This is not irrelevant to the modern paganism of media and (since we learn through what consists our being), the notion of existence during a specific period and its context within a certain life.

In both cases, paganism objects against inwardness and inwardness is the crucial notion to differentiate Kierkegaard's existential subjectivity from the socially determined subjectivity of social media. Actually, what Climacus calls the 'absolute paradox' is the last thing that separates existential inward faith according to Kierkegaard's philosophy from the mediated faith of fake news and their hegemonic, yet, personal, normativity. The Absolute Paradox does not address itself as an issue from an 'objective' point of view. It does not claim that it represents the naturalized language of the collective society, although services particular interests. Its pure form, which consists its only 'real' form, is not involved in any institution although those can easily manipulate it. 'When Climacus, therefore, speaks of the paradox as absolute, what he means is that only an existential (subjective) response to the question is possible' (Schönbaumsfeld 2010:132) Kierkegaard's subjectivity is open despite it addresses itself into a dogma. Fake news subjectivity is closed although it addresses itself into a superficial pluralism of postmodernity.

\section{THE SELF IN THE FAKE NEWS ERA: A VIRTUAL RITUALISATION IN PROCESS}

Where all these evolutions lead the concept of the Self? In reality, whereas the self-sustaining subject at the centre of post-Cartesian western philosophy has been comprehensively advanced, the endlessly performative self (Butler 1993; Quinn 2003) continually being scripted by hegemonic social conventions and ideologies (Felluga 2006) has been the critical conception of cultural identity in this new mediated environment. Nevertheless, this is what makes Kierkegaard more relevant than ever. The question of subjectivity and its unconscious processes of formation and perpetual evolution was at the very centre of Kierkegaardian philosophy. His quest for authenticity of the human subject, his notion of the personal responsibility of the thinking the acting, the feeling, and the living human individual against the whole world and the big narratives of society and religion that tried to disempower him, the existential attitude (Stack 1973: 109), as a sense of disorientation, does describe the voyage and the urge of our era.

His sense of disorientation was a genuine feeling 'of the bugbear that spurred the rulers and the philosophers into ordering and legislating frenzy'. What Kierkegaard did was to introduce the original vagabond in the philosophy of modernity. Moreover, 
to quote Bauman (2011: 28), '[h]is human subject was masterless, not responsibleness, and being masterless was one condition power could not bear and thus spent the rest of history fighting'. That gave an excellent sense of a direction in order of an authentical identity to be found.

Nevertheless, throughout modernity identification was constructed having recognition of a homogenous characteristic (based on race, colour, religion, nation, sexuality, class) that makes you fit in, excluding Others. Even so, viewing culture as dynamic, and identity as constructed continuously and negotiated, having humanity to face the rapid changes in social cultural and financial level that signalled the passage from modernity to postmodernity, identification itself became a construction, a process never completed - always 'in process' including (and excluding) superficially anything. It is not determined, and every minute can be sustained or abandoned. Every minute can create a 'new Self' and a 'New Other', depending on the needs of social cohesion and geopolitics. Though not without its determinate conditions of existence identification is, in the end, an Introduction (Hall 1996: 2-3).

Like any other introduction, the concept of identification inherits a rich semantic legacy that addresses itself not just to the core of the 'Self' but also to the core of the 'Other'. Introduction demands an audience, and an audience is constructed under the influence of a quest. Such a quest is magnified in this era of social media where anything private becomes public. Northrop Frye identifies the central myth of humanity, in its narrative aspect, with the quest myth. He sees the significance of the quest myth as Frye pointed 'in its vision of the end of social effort, the innocent world of fulfilled desires, the free human society' (Dunham 1996: 133). Thus, the quest-myth is an Archetype of the biblical paradise, hidden under various political-cultural or metaphysical manifestations that shape the Self and the Other all those centuries. Located in our psyche, it is the repository of shared memory, an inheritance from our common ancestors. Hence, our narrative stories are ritualised events (Swchartzman 1979) or the public expressions of our private experiences. In a way, reality (actual or imagined) of any group or collectivity was preconditioned inside fiction and vice versa, sustaining its cohesion and world view at a global level.

This was the world where the Kierkegaardian Self should oppose in order to find its destiny and through it its decency. However, what is the impact in an era in which our narrative stories do not express primarily any collectivity (although they still carry at some extent their - anything but neutral - common-sense) but primarily the view of oneself, a self-shaped and formed in a world where no collectivity has the right to consider itself 'holly'?

This painful presence of an absence (the absence of holly of one truth), this deep cataclysmic loneliness inside of social media, creates the need to reverse it, to make it your own, to transform it into its total opposite, creating a convenient absence of a presence (of reality) creating, using and spreading Fake News, mediated identities and wor(l)ds.

In fact, Fake News is not a new phenomenon, but due to the spread of social media in a globalised economy and world, it has become more prevalent. In 2018, an MIT study by Soroush Vosoughi, Deb Roy, and Sinan Aral found that Fake News and their 
'realities' now spread faster than real news. It is like trying to interfere in the cataclysmic controversial and anything but a coherent ocean of information promoting one's own set of beliefs. Since these beliefs were influenced in a pre-given context of internalised hierarchies and stereotypes, they tend to reproduce the previous givens of monoculture and nation-state. This is why the majority of Fake News reproduce, empower and circulate modern populism, typing up conspiracy theories that hurts the socio-political order of the planet so much. 'Fanatism is the only will can have people that never a will of their own', to quote Nietzsche.

\section{CONCLUSION: A NEW AGAINST AN OLD PARADOX?}

While the need to believe the way Climacus explains, it reminds us of the need to open ourselves to the multiple variations of subjectivity and its choices, to open ourselves to the tremendous possibilities of a controversial world in need of inward peace. The choice to believe in Fake News reveals a deep need to manipulate outer reality at a personal level in order to ease the magnified anxiety that modern, multicoated world -where no alternative seems to exist- creates, depressing the postmodern social subject.

However, Fake News remains harmful. According to the Future of Truth and Misinformation Online research (Anderson and Raine 2017), 'it can spread untruths about events, people and situations. It can target certain groups in society who may be vulnerable, such as people with mental health problems or refugees or believers or people with different sexual orientation or women, or political opponents in certain regimes. It can discriminate and cause hatred against certain groups'.

The need to abandon one's Self and responsibility as a free-thinking citizen for a fake reality is a manifestation of broader issues in the modern information environment that impact the knowledge and through it the possibility to be information literate. Even if this fakery supports the subject's needs for security and recognition (a kind of postmodern virtual paganism based on ritual and not material), or for any identification, this impacts the possibility to be less recognized and more human. If we think about it, in an era where our certainties have become fluid, the mediated identities are the only certainty we have. In that sense fake becomes the new ritual, taking along in its shift the self.

\section{A RITUALISED SELF}

Rituals have many continually evolving forms of expression that act as a 'system of values, ideas and practices'. This multicoated system functions as an essential tool to establish an order which will enable individuals to orientate themselves in their material and social world. However, this orientation is never completely independent from the broader social and cultural establishments, within the framework of which communication takes place among the members of a community.

By definition, this means that the Self who addresses itself to an audience, the Public Self, accepts to be mediated. Nevertheless, the self we project in Social Media is 
Public and entails necessarily way more narcissistic elements than our private one. Likewise, our identity is way more ritualized than in the past.

This is what makes Fake News so well received. Those who participate in Fake News are not exclusively or are not always reclusive figures, sharing populistic political views and conspiracy theories on their website, blog or social media. However, in reality, the successful creation of Fake News involves many people, and many agencies, and some of them may not even realize they are part of it.

Fake News is convenient, they create not a reality but our 'personal' (?) reality, fitting in the box of our political or ethnic or religious or gender or class world view. Our self becomes not masterless as Kierkegaard or Bauman wanted, but responsibleness. Moreover, responsible is the exact opposite of masterless.

The popularity of Fake News is not irrelevant to the way the human subject is being constructed these days. While in the traditional societies the social cohesion was constructed using the Unheimlich as an enemy, which led to the Ideal National (aka Collective) Self, in neoliberal societies of post-modernity the new Unheimlich is critical thinking and alas reality itself. The bitter irony, so close to Kierkegaard's critique to the press of his era, is that critical thinking led to a notion of pedagogy that the educational praxis was identified with the creation not of a full mind (meaning full of information) but of an open mind: 'Neither belief is a hypothesis, and even if it were one, there would not be any absolute justification for it. As he puts it: Well, if everything speaks for a hypothesis and nothing against it - is it then certainly true? One may designate it as such. - However, does it certainly agree with reality, with the facts? - With this question you are already going round in a circle' (Kierkergaard 1992: 191).

Nevertheless, the open social space of contemporarily, linked with the sociological imagination (Giddens 1996), might lead to an ambiguous future of information, where our more personal space might be manipulative and under manipulation. First by ourselves and then by convincing 'others'.

Judeo-Christian culture, writes Richard Sennett (Ritivoi 2002: 26) 'is, at its very roots, about experiences of spiritual dislocation and homelessness (...) Our faith began at odds with place'. Nowadays, as we have been catapulted in the chaos of the postmodern mediated world, the only place we got is this invented Self. Identities are about questions of using the resources of history, language and culture in the process of becoming rather than being: partly constructed in fantasy, or at least within a fantastic field, fit in this communication of disinformation spread via traditional media or online social media. We truly live in a world where we trick first ourselves and then the Others. However, in this way, we become our Inner Other ourselves. Kierkegaard's quest for authenticity in subjectivity still knocks our door.

FUNDING: This research received no external funding.

CONFLICT OF INTEREST: The author declares no conflict of interest. 


\section{REFERENCES}

Adorno, Theodor. 2017. Minima Moralia: Reflections on a Damaged Life. Athens: Paratiritis.

Beaney, Michael. 2003. “Analysis.” in Stanford Encyclopedia of Philosophy (Summer 2018 Edition), edited by Edward N. Zalta. Retrieved September 05, 2019 (https:// plato.stanford.edu/archives/sum2018/entries/analysis/).

Bauman, Zygmunt. 1992. "Cultural Theory and Cultural Change: Survival as a social construct.” Pp. 112-126 in Cultural Theory and Cultural Change, edited by M. Featherstone. London: Sage.

Bauman, Zygmunt. 2011. “From Pilgrim to Tourist, a Short History of Identity.” Pp. 1836 in Questions of Cultural Identity, edited by P. Hall and Paul Du Gay. Thousand Oaks, CA, US: Sage Publications, Inc.

Bauman, Zygmunt. 2011. “Migration and Identity in the Globalised World.” Philosophy \& Social Criticism 37(4): 425-435. https://doi.org/10.1177/0191453710396809

Baur, Jürgen and Sebastian Braun. 2000. Freiwilliges Engagement und Partizipation in ostdeutschen Sportvereinen: eine empirische Analyse zum Institutionentransfer. Köln: Strauß.

Beck, Urlich. 1992. Risk Society: Towards a New Modernity. London: Sage.

Bette, Karl-Heinrich. 1999. Systemtheorie und Sport. Frankfurt am Main: Suhrkamp.

Binder, Susanne and Jelena Tošić. 2005. "Refugees as a Particular Form of Transnational Migrations and Social Transformations: Socioanthropological and Gender Aspects.” Current Sociology 53(4): 607-24. DOI: 10.1177/0011392105052717.

Butler, Judith. 1993. Bodies that Matter. On the Discursive Limits of Sex. London and New York: Routledge.

Denham, Robert. 1996. Collected Works of Northrop Frye: The educated imagination and other writings on critical theory 1933-1963. Toronto CA: University of Toronto Press.

Douglas, Kellner. 1992. “Popular culture and constructing postmodern identities.” Pp. 141-177 in Modernity and Identity, edited by Scott Lash and Jonathan Friedman. Oxford UK: Basil Blackwell.

Durham, Gigi. 2008. The Lolita Effect: The Media Sexualization of Young Girls and What We Can Do About It. London: Harry N. Abrams.

Fornas, Johan and Xinaris Charis. 2013. “Mediated Identity Formation.” Current Trends in Research and Society, Journal of the European Institute for Communication and Culture 20(2): 11-26.

Giddens, Anthony. 1996, Sociological Imagination: Introduction to Sociology. New York: W. W. Norton \& Company.

Hall, Stuart and Paul Du Gay, eds. 2011. Questions of Cultural Identity. London UK: Sage Publications.

Kierkergaard, Søren. 1992. Concluding Unscientific Postscript to Philosophical Fragments, edited and translated by Howard and Edna Hong. Princeton: Princeton University Press.

Leydesdorff, Loet. 2000. A Sociological Theory of Communication: The Self-Organization 
of the Knowledge-Based Society. Irvin Ca US: Universal Publishers.

Lyotard, Jean Francois. 1979. The Postmodern Condition: A Report on Knowledge. Minnesota US: University of Minnesota Press.

Maffesoli, Michel. 1996. The Time of the Tribes: The Decline of Individualism in Mass Society. London: Sage.

McMillin, Divya. 2009. Mediated Identities: Youth, Agency, and Globalization in Mediated Youth. New York US: International Academic Publishers.

Quinn, Robert. 2003. “The Performative Self: Improvisation for Self and Other.” New Theatre Quarterly 19(1): 18-22.

Ritivoi, Andreea Deciou. 2002. Yesterday's Self: Nostalgia and the Immigrant Identity. Maryland BA: Rowman and Littlefield.

Riva, Giusepe and Galiberti Carlo. 1998. “Computer-mediated communication: Identity and social interaction in an electronic environment in Genetic Social and General Psychology.” Monographs 124(4): 434-464.

Stack, George. 1973. “Kierkegaard: The Self and Ethical Existence.” Ethics 83(2): 108125.

Star, Christopher. 2012. The Empire of the Self. Self-Command and Political Speech in Seneca and Petronius. Maryland BA: John Hopkins University Press.

Swhartzman, Helen. 1979. Transformations: The Anthropology of Children's Play. London, UK: Plenum Press.

Silverstone, Roger. 2005. “The Sociology of Mediation and Communication.” Pp. 188207 in The Sage Handbook of Sociology, edited by C. Calhoun, Ch. Rojek and B. Turner. London UK: Sage Publications.

Schönbaumsfeld, Genia. 2010. “Objectively there is no truth - Wittgenstein and Kierkegaard on Religious Belief.” Pp. 131-147 in Ludwig Wittgenstein on Ethics, Mysticism and Religion, edited by U. Arnswald. KIT: Scientific Publishing.

Shakespeare, William. 2013. The Tempest. Cambridge: Cambridge University Press.

\section{WEBOGRAPHY}

Anderson, Janna and Rainie, Lee. The Future of Truth and Misinformation Online. Retrieved August 31, 2018 (http://www.pewinternet.org/2017/10/19/the-future-of-truth-and-misinformation-online/).

Felluga, D. 2006. Modules on Butler II: Performativity. Retrieved August 31, 2018 (https://www.cla.purdue.edu/academic/english/theory/genderandsex/modules/ butlerperformativity.html).

Soroush Vosoughi, Deb Roy, and Sinan Aral. 2018. The Performative Self Who are we now that We're Online? Connected Learners, Connected Educators. Science 359: 1146-1151. Retrieved August 31, 2018 (http://science.sciencemag.org/content/359/6380/1146). 


\section{BIOGRAPHICAL NOTE}

Eleni Karas works at the Department of Primary Education, University of Ioannina, Greece.

OPEN ACCESS: This article is distributed under the terms of the Creative Commons Attribution Non-commercial License (CC BY-NC 4.0) which permits any non-commercial use, and reproduction in any medium, provided the original author(s) and source are credited.

ARTICLE HISTORY: Received 2019-01-09 / Accepted 2019-12-03 
